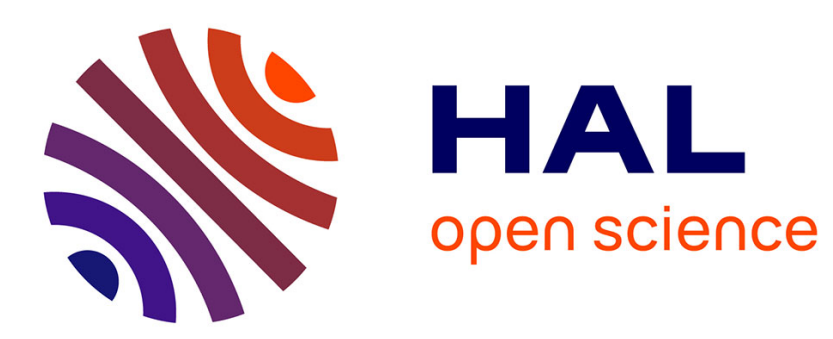

\title{
Fitness consequences of seed size in the valley oak Quercus lobata Née (Fagaceae)
}

Richard Sage, Walter Koenig, Blair Mclaughlin

\section{To cite this version:}

Richard Sage, Walter Koenig, Blair Mclaughlin. Fitness consequences of seed size in the valley oak Quercus lobata Née (Fagaceae). Annals of Forest Science, 2011, 68 (3), pp.477-484. 10.1007/s13595011-0062-6 . hal-00930796

\section{HAL Id: hal-00930796 https://hal.science/hal-00930796}

Submitted on 1 Jan 2011

HAL is a multi-disciplinary open access archive for the deposit and dissemination of scientific research documents, whether they are published or not. The documents may come from teaching and research institutions in France or abroad, or from public or private research centers.
L'archive ouverte pluridisciplinaire HAL, est destinée au dépôt et à la diffusion de documents scientifiques de niveau recherche, publiés ou non, émanant des établissements d'enseignement et de recherche français ou étrangers, des laboratoires publics ou privés. 


\title{
Fitness consequences of seed size in the valley oak Quercus lobata Née (Fagaceae)
}

\author{
Richard D. Sage • Walter D. Koenig • \\ Blair C. McLaughlin
}

Received: 24 May 2010 /Accepted: 24 November 2010 / Published online: 7 April 2011

(C) INRA and Springer Science+Business Media B.V. 2011

\begin{abstract}
- Introduction We examined the functional relationship between seed size and seedling performance in the valley oak (Quercus lobata Née) by means of a 13-year common garden experiment.

- Materials and methods Acorns were collected from five localities throughout the range of valley oak in autumn 1997, weighed and measured, and planted at Sedgwick Reserve, Santa Barbara County, California, USA.

- Results In the short term, larger acorns produced larger seedlings that had lower survival than seedlings from smaller acorns. In the longer term, large seeds correlated positively with both seedling size and survival, with path analyses indicating that the latter effect was primarily indirect via initial seedling size. The longer-term relative growth rate was only weakly related to seed size, being a combination of a slight positive direct influence of seed size on relative growth rate and a comparable negative indirect effect via larger initial seedling size.

- Discussion These results generally matched the predictions of the "seedling size effect hypothesis" (larger seeds
\end{abstract}

Handling Editor: Douglass Jacobs

R. D. Sage

Department of Ecology, Evolution, and Marine Biology,

University of California,

Santa Barbara, CA 93106, USA

W. D. Koenig $(\bowtie)$

Lab of Ornithology and Department of Neurobiology

and Behavior, Cornell University,

159 Sapsucker Woods Road,

Ithaca, NY 14850, USA

e-mail:wdk4@cornell.edu

B. C. McLaughlin

Environmental Studies, University of California,

Santa Cruz, CA 95064, USA yield larger seedlings with greater competitive abilities), the only one of the three hypotheses we examined that predicts an inverse relationship between seed size and initial survival and a positive relationship between seed size and longer-term relative growth rate. The factors influencing the relationships between seed size and seedling performance are complex and may involve both direct effects of seed size and indirect effects mediated through initial seedling size. Although the seedling size effect was the most important in our study, other factors may be important under different environmental conditions and/or at different growth stages.

Keywords Acorn size · Fagaceae - Quercus lobata Reserve effect $\cdot$ Seed size $\cdot$ Seedling size effect $\cdot$ Valley oak

\section{Introduction}

Numerous studies have demonstrated that larger seeds enhance seedling performance. However, the mechanisms by which this effect is achieved appear to be diverse and variable. Currently, three hypotheses are thought to be potentially important to this observation (Westoby et al. 1996). First is the "reserve effect," whereby larger seeds retain extra metabolic resources that can be used to enhance survival if conditions are unfavorable (García-Cebrián et al. 2003; Green and Juniper 2004a; Myers and Kitajima 2007). Second is the "metabolic effect," whereby seedlings from larger seeds have slower relative growth rates and consume resources more slowly, thus potentially enhancing longterm survival (Saverimuttu and Westoby 1996; Wright and Westoby 1999). Third is the "seedling size effect," whereby larger seeds produce larger seedlings that are better competitors and thus better able to gain greater access to resources.

To date, most tests of these hypotheses have involved interspecific or interpopulation comparisons in which 
allocation-based trade-offs are expected (Kitajima 1994; Westoby et al. 1996; Kitajima 2002; Green and Juniper 2004a, b). Other studies have been conducted on annual plants or over relatively short time periods, neither of which are designed to detect longer-term effects of seed size (Stanton 1984; Ke and Werger 1999; Green and Juniper 2004b; Quero et al. 2007). An exception is the study by Baraloto et al. (2005), who examined effects of seed mass in two large-seeded neotropical tree species over 5 years and found strong effects of initial seedling size on subsequent seedling performance. Their results provided mixed support for the seedling size hypothesis, which was countered primarily by a failure to find a positive correlation between seedling size and long-term survivorship in one of the species in a path analysis taking into account both direct and indirect effects.

Distinguishing among these three hypotheses is complicated by the fact that a positive correlation between seed size and initial seedling size is likely under all three (Quero et al. 2007). Furthermore, under at least some circumstances, all assume that larger size enhances the fitness of seeds. They are, however, expected to affect different components of fitness (Table 1). Any advantage of the reserve effect, for example, is specific to survival under adverse conditions, even if it comes at the expense of faster growth and larger seedling size. As originally proposed, the advantages of large seed size via the reserve effect are explicitly temporary and are not expected to confer longterm survival or size benefits (Westoby et al. 1996). Although it has been suggested more recently that seeds might transfer reserves to other parts of the plant for later deployment, works by García-Cebrián et al. (2003), Kennedy et al. (2004), and Quero et al. (2007) do not support the hypothesis that seed reserves influence seedling oaks (Quercus spp.) or tanoak (Notholithocarpus densiflorus) beyond a short initial period of 1 to 2 months. Thus, in the short term, the reserve effect is expected to yield a positive correlation between seed size and initial seedling survival but is consistent with either a positive or a negative relationship between seed size and initial seedling size. In the long term, the reserve effect predicts no significant relationship (neither positive nor negative) between seed size and either seedling growth rate or survival.

The metabolic effect proposes that the relative growth rate of large seeds is slower, conferring a survival advantage under unfavorable conditions (Westoby et al. 1996). Thus, this hypothesis predicts a positive relationship between seed size and initial survivorship; it is also most consistent with a negative correlation between seed size and seedling size, particularly under harsh conditions when the survival advantage is most likely to be expressed. In the long term, the metabolic effect should enhance seedling survival, at least under adverse conditions, while predicting no relationship between seed size and long-term relative growth rate.

Finally, the seedling size effect proposes that large seeds provide advantages in terms of competition, both for light aboveground and for water and nutrients belowground (Foster 1986; Metcalfe and Grubb 1997; Lloret et al. 1999). Thus, the seedling size effect specifically predicts a positive correlation between seed size and initial seedling size. However, this large investment in growth is likely to come at a cost to seedling survival (Stearns 1989). Thus, this hypothesis is the only one consistent with a negative correlation between seed size and short-term seedling survival. In the longer term, larger seedlings are likely to benefit from their greater access to resources by experiencing both enhanced growth rate and enhanced survival, thus predicting a positive correlation between seed size and both these fitness components.

These contrasting predictions open the door for testing these hypotheses from a functional perspective using data on seedling survival and growth gathered on both a shortterm and longer-term basis. Here, we perform such a test by means of a 13-year common garden experiment on valley oak (Quercus lobata Née), a large-seeded, endemic species common in California woodlands and savannas (Pavlik et al. 1991) of particular conservation concern due to low recruitment (Tyler et al. 2006; Zavaleta et al. 2007) and projected losses due to climate change (Kueppers et al. 2005).
Table 1 Predictions of the fitness consequences of three hypotheses for the relationship between seed mass and seedling performance

Observed relationships based on the results are presented, with the path analyses in Fig. 4 indicating whether significant effects are direct or indirectly mediated through seedling size

+ positive relationship,

- negative relationship,

○ no relationship predicted

\begin{tabular}{lllll}
\hline & \multicolumn{2}{l}{ Relationship with seed size } & \\
\cline { 2 - 5 } $\begin{array}{l}\text { Fitness } \\
\text { component }\end{array}$ & $\begin{array}{l}\text { Reserve } \\
\text { effect }\end{array}$ & $\begin{array}{l}\text { Metabolic } \\
\text { effect }\end{array}$ & $\begin{array}{l}\text { Seedling } \\
\text { size effect }\end{array}$ & Observed \\
\hline $\begin{array}{l}\text { Initial seedling } \\
\text { survivorship }\end{array}$ & + & + & - & - \\
$\begin{array}{l}\text { Initial seedling } \\
\text { size }\end{array}$ & $+/-$ & $+/-$ & + & + \\
$\begin{array}{l}\text { Long-term seedling } \\
\text { survivorship }\end{array}$ & 0 & + & + & + (indirect) \\
$\begin{array}{l}\text { Long-term } \\
\text { relative growth rate }\end{array}$ & 0 & 0 & + & - (indirect) \\
\hline
\end{tabular}




\section{Materials and methods}

Acorns used in the study were collected from mother trees during October-November 1997 in five localities spanning the latitudinal distribution of valley oak, which is entirely within the state of California, USA (Fig. 1). Mature acorns were collected from the trees or from the ground directly below the trees in situations where maternity was unambiguous. Acorns that were obviously damaged or parasitized were avoided, but otherwise were chosen randomly, untreated, and kept cool and dry until sowing. Size of acorns, determined from their length and width measured to the nearest $0.1 \mathrm{~mm}$, was estimated by the formula for a prolate spheroid $\left(4 / 3 \times \pi \times\right.$ length $\times$ width $\left.^{2}\right)$. Mass of the intact acorns was determined to the nearest $0.01 \mathrm{~g}$.

Acorns were planted in November 1997 at Sedgwick Reserve, Santa Barbara County, in a grid located in a flat

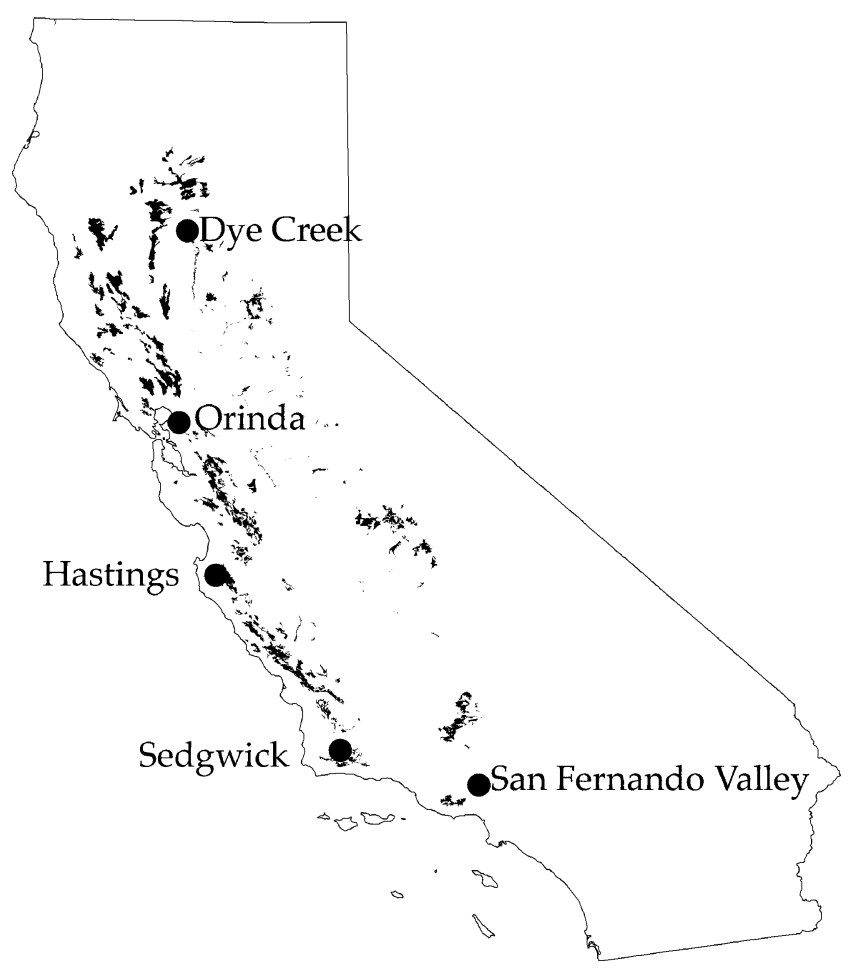

Fig. 1 A map of California, USA, showing the geographic range of valley oaks (dark areas), the five localities from which acorns were collected, and the location of the common garden experiment, which was conducted at Sedgwick Reserve. From N-S, the localities were (1) Cone Grove Park-Dye Creek, 85 m elevation, Tehama Co. $\left(40^{\circ}\right.$ $\left.10^{\prime} 3.24^{\prime \prime} \mathrm{N}, 122^{\circ} 8^{\prime} 7.51^{\prime \prime} \mathrm{W}\right)$; (2) Orinda Village $\left(37^{\circ} 52^{\prime} 59.84^{\prime \prime} \mathrm{N}, 122^{\circ}\right.$ $\left.11^{\prime} 23.73^{\prime \prime} \mathrm{W}\right)$ and Briones Regional Park $\left(37^{\circ} 55^{\prime} 38.63^{\prime \prime} \mathrm{N}, 122^{\circ} 9^{\prime}\right.$ 30.33"W), 132-211 m, Contra Costa Co.; (3) Hastings Reservation - upper Carmel Valley, $533 \mathrm{~m}$, Monterey Co. $\left(36^{\circ} 23^{\prime} 6.10^{\prime \prime} \mathrm{N}, 121^{\circ} 33^{\prime}\right.$ 3.57"W); (4) Sedgwick Reserve - Santa Ynez, 350-380 m, Santa Barbara Co. $\left(34^{\circ} 41^{\prime} 53.85^{\prime \prime} \mathrm{N}, 120^{\circ} 2^{\prime} 27.92^{\prime \prime} \mathrm{W}\right)$; and (5) the San Fernando Valley area, including Agoura Hills $\left(34^{\circ} 8^{\prime} 34.78^{\prime \prime} \mathrm{N}, 118^{\circ} 45^{\prime}\right.$ $\left.42.66^{\prime \prime} \mathrm{W}\right)$, Calabasas $\left(34^{\circ} 9^{\prime} 15.03^{\prime \prime} \mathrm{N}, 118^{\circ} 38^{\prime} 45.53^{\prime \prime} \mathrm{W}\right)$, Woodland Hills $\left(34^{\circ} 10^{\prime} 6.19^{\prime \prime} \mathrm{N}, 118^{\circ} 36^{\prime} 19.24^{\prime \prime} \mathrm{W}\right)$, and West Hills $\left(34^{\circ} 13^{\prime} 4.90^{\prime \prime} \mathrm{N}, 118^{\circ} 38^{\prime}\right.$ 25.99"W), 265-310 m, Los Angeles Co area along the flood plain of the Figueroa Creek, approximately $800 \mathrm{~m} \mathrm{NNE}$ of the reserve headquarters. The elevation of the plot was $300 \mathrm{~m}$ and the mean annual precipitation $38 \mathrm{~cm}$; for additional details regarding the reserve, see http://sedgwick.ucnrs.org/. From each of the eight mother trees from each of the five collecting sites, 11 sets of four randomly selected and individually numbered acorns of known size (440 sets of acorns in all) were planted in $60 \times 23 \mathrm{~cm}$ wire baskets placed within $30 \times 23 \mathrm{~cm}$ auger-drilled holes bored into the soil on a $21 \times 21 \mathrm{~m}$ grid with $2 \mathrm{~m}$ between baskets. Thus, baskets protruded $30 \mathrm{~cm}$ above ground level after being set into the bored holes and allowed roots to grow into the soil below the basket. After placement, the removed dirt was returned to the holes followed by $5 \mathrm{~cm}$ of bark mulch to inhibit weed growth and netting attached to the top with wire and a staple, allowing access to the inside of the basket to inspect seedlings. All sets of acorns were assigned randomly to a basket with respect to their locality of origin and mother tree.

Subsequent censuses of the survival and size of the seedlings were made on four occasions. The first census was in June 1998, approximately 7 months following planting, at which time baskets were weeded and all but one randomly chosen seedling was carefully removed from each basket containing surviving seedlings. As a measure of growth, we used the maximum height of stems, measured to the end of the highest stem tip and excluding any protruding leaves. During the following winter, approximately half of the baskets were watered, with the watering treatment randomized within baskets containing acorns of each mother tree. The second seedling survey was conducted in January 1999 when seedlings were approximately 14 months old, at which time weeds were again removed and the maximum height of shoots was measured. The third census was made in late summer 2002 when seedlings were approximately 5 years old. At that time, both the maximum stem height and basal diameter of seedlings were measured and baskets impeding the growth of seedlings were opened, exposing seedlings to natural browsing by deer. The fourth and final census was made in September 2010 when seedlings were approximately 13 years old. At that time, both maximum stem height and diameter of shoots were measured. When more than one main shoot was present, their diameters were combined to yield a value corresponding to a single sprout with the same basal area as that of the combined shoots present.

Although we provide data for stem diameter when available, we used maximum stem height as the main proxy of fitness for two reasons. First, it was possible to measure it during all surveys, and thus, it provided the best measure of growth rate we were able to obtain without destructive sampling. Second, growing above the height at which most grazers are able to reach is a primary means 
trees have of circumventing browsing by native herbivores and grazing by domestic animals, a major limitation of recruitment of $Q$. lobata and several other species of California oaks (Tyler et al. 2006). Thus, the rate at which seedlings increase in height is likely to play an important role in recruitment and thus fitness in this species. Finally, the two measures were highly correlated, both when measured during the summer 2002 survey $(\ln [\mathrm{stem}$ height $]=1.05(\ln [$ stem height $])+1.14, \quad F_{1,299}=438, \quad P<$ 0.0001 ) and when measured during the final survey in September 2010 (Fig. 2).

Seedling relative growth rate (RGR) was calculated as $(\ln$ (height at date 2$)-\ln ($ height at date 1$)) /($ time interval) (Baraloto et al. 2005) for the period between planting and the first survey (0-7 months; this is equivalent to growth at the time of the first survey), and between the first and remaining surveys ( $7-14$ months, 7 months -5 years, and 7 months -13 years). Analyses of seedling growth rate and survival were made using linear mixed-effects models with both locality of origin and maternal tree included as random effects and maternal tree nested within locality; binomial error terms were assumed for the survival analyses. Whether seedlings were watered or not was included in analyses of survival and maximum height at the second (14 months) survey. However, neither this variable nor its interaction was significant (most likely because the winter of 1998-1999 was relatively wet and thus water was not limiting), and they are thus not discussed further. Finally, in order to look at potential direct and indirect effects on seedling survival and performance, we performed a path analysis with the strength of causal relationships between seed size, initial seedling size, long-term seedling survival,

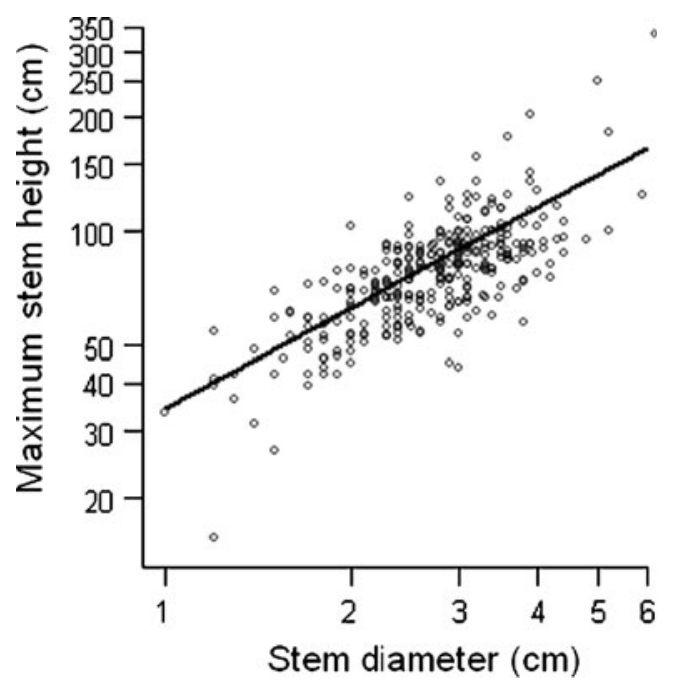

Fig. 2 Regression of maximum stem height on stem diameter (both on a $\log$ scale) at the final survey in September 2010 when saplings were 13 years old. Formula: $\ln [$ stem height $]=0.80(\ln [$ stem diameter] $)+3.56$ $\left(F_{1,303}=458, P<0.0001\right)$. Range of stem height was $7-341 \mathrm{~cm}$; range of stem diameter was $0.1-6.2 \mathrm{~cm}$ and RGR estimated by the standardized partial regression coefficients of multiple regressions using the data from the final (13 years) survey. All statistical tests were conducted in R 2.10.0 (R Development Core Team 2009).

\section{Results}

\subsection{Seed size variation}

Acorns used in the plantings ranged in estimated volume from 1.02 to $17.35 \mathrm{~cm}^{3}$ (mean $\pm \mathrm{SD}=6.36 \pm 2.45 \mathrm{~cm}^{3} ; \quad N=$ $1,471)$ and mass between 0.48 and $3.20 \mathrm{~g}($ mean $\pm \mathrm{SD}=1.35 \pm$ $0.45 \mathrm{~g} ; N=332$ ). There was a strong correlation between these two measures of size $(r=0.81, d f=320, \quad P<0.001)$, both of which differed significantly among sites (one-way analysis of variance, estimated volume $F_{4,1466}=92.0, P<0.001$; acorn mass $\left.F_{4,317}=13.3, P<0.001\right)$. Estimated volume was not normally distributed (Shapiro test $W=0.958, P<0.001$ ) but was normalized by fourth-root transformation (Shapiro test $W=0.998, P=0.06$ ). Mass was also non-normally distributed (Shapiro test $W=0.965, P<0.001$ ) but was normalized by log transformation (Shapiro test $W=0.995, P=0.45$ ). Thus, these transformations were used in all subsequent statistical analyses.

\subsection{Seedling survival}

Initial seedling survival was determined from planting to 7 months of age when the first survey took place. At that time, general linear models controlling for locality revealed a significant negative effect of estimated acorn volume on seedling survival; the relationship between acorn mass and survival was not significant (Table 2).

Subsequent censuses determined survival from the time of the first census at 7 months (Table 2). Survival to 5 years, the time of the third census, was $95.7 \%$, at which point there was a significant positive effect of both acorn mass and acorn volume. Survival to the final census at age 13 was $93.8 \%$, at which time there was still a significant positive effect of acorn mass, but not estimated acorn volume, on survivorship.

\subsection{Seedling size and relative growth rate}

There were highly significant, positive effects of acorn size (both estimated volume and mass) on both maximum shoot height and trunk diameter in all surveys (Table 2; Fig. 3a). When measured as RGR between the first survey at 7 months and subsequent surveys, there was generally no relationship, but the relationship became significantly negative between acorn volume and RGR by the time trees were 5 years old (Table 2; Fig. 3b). 
Table 2 Results of linear mixed-effects models explaining maximum seedling height and RGR (between the first and subsequent surveys) as a function of initial estimated acorn volume and mass

\begin{tabular}{|c|c|c|c|c|c|c|}
\hline & \multicolumn{3}{|l|}{ Acorn volume } & \multicolumn{3}{|l|}{ Acorn mass } \\
\hline & Effect size \pm SE & $t$ value $(d f)$ & $P$ value & Effect size \pm SE & $t$ value $(d f)$ & $P$ value \\
\hline \multicolumn{7}{|l|}{ Survivorship } \\
\hline Initial (7 months) & $-0.89 \pm 0.42$ & -2.15 & 0.03 & $0.17 \pm 2.83$ & 0.10 & 0.9 \\
\hline 5 years & $3.23 \pm 1.12$ & 2.88 & 0.004 & $5.83 \pm 2.40$ & 2.42 & 0.015 \\
\hline 13 years & $1.61 \pm 1.94$ & 0.83 & 0.4 & $2.10 \pm 0.87$ & 2.41 & 0.016 \\
\hline \multicolumn{7}{|c|}{ Maximum seedling height } \\
\hline Initial (7 months) & $1.15 \pm 0.15$ & $7.9(407)$ & $<0.001$ & $0.32 \pm 0.06$ & $4.9(210)$ & $<0.001$ \\
\hline 14 months & $1.16 \pm 0.20$ & $5.8(183)$ & $<0.001$ & $0.36 \pm 0.09$ & $4.2(180)$ & $<0.001$ \\
\hline 5 years & $0.76 \pm 0.15$ & $4.9(245)$ & $<0.001$ & $0.33 \pm 0.06$ & $5.2(241)$ & $<0.001$ \\
\hline 13 years & $0.47 \pm 0.14$ & $3.3(249)$ & $<0.001$ & $0.24 \pm 0.06$ & $4.0(245)$ & $<0.001$ \\
\hline \multicolumn{7}{|l|}{ Seedling diameter } \\
\hline 5 years & $6.7 \pm 1.1$ & $6.1(245)$ & $<0.001$ & $3.0 \pm 0.5$ & $6.5(241)$ & $<0.001$ \\
\hline 13 years & $11.2 \pm 3.4$ & $3.3(249)$ & 0.001 & $4.9 \pm 1.4$ & $3.4(245)$ & $<0.001$ \\
\hline \multicolumn{7}{|c|}{ RGR (seedling height) } \\
\hline $7-14$ months & $0.05 \pm 0.43$ & $0.1(189)$ & 0.9 & $0.17 \pm 0.19$ & $0.9(186)$ & 0.4 \\
\hline 7 month -5 years & $-0.14 \pm 0.07$ & $-2.0(90)$ & 0.045 & $-0.02 \pm 0.03$ & 0.7 (89) & 0.5 \\
\hline 7 month-13 years & $-0.042 \pm 0.016$ & $-2.6(196)$ & 0.011 & $-0.007 \pm 0.007$ & $-1.0(193)$ & 0.3 \\
\hline
\end{tabular}

Data are grouped by maternal tree within the site of origin; variables are transformed as discussed in the text

\subsection{Path analysis}

The results of path analyses measuring the effects of seed size on seedling performance confirmed the strong positive, direct effect of seed size on initial seedling height and the strong negative relationship between initial height and long-term RGR (Fig. 4). The relationship between seed size and longterm survival was weak, being made up of a small negative direct effect and a small positive indirect effect through initial seedling height. The relationship between seed size and long-term RGR was similarly composed of an opposing positive direct effect (significant in the case of seed mass) and a negative indirect effect through initial seedling height.

\section{Discussion}

Valley oak acorns vary considerably in size both among trees and among years (Koenig et al. 2009a). As found here, they also vary among sites and within populations, a feature in common with other species of North American oaks (Aizen and Patterson 1990; Aizen and Woodcock 1992; Koenig et al. 2009b). Here, we investigated the fitness consequences of variable seed size in terms of their effects on survival and seedling growth with the goal of discriminating among three hypotheses for the generally positive relationship observed between seed mass and seedling performance. These included the reserve effect (larger seeds retain a larger proportion of reserves after
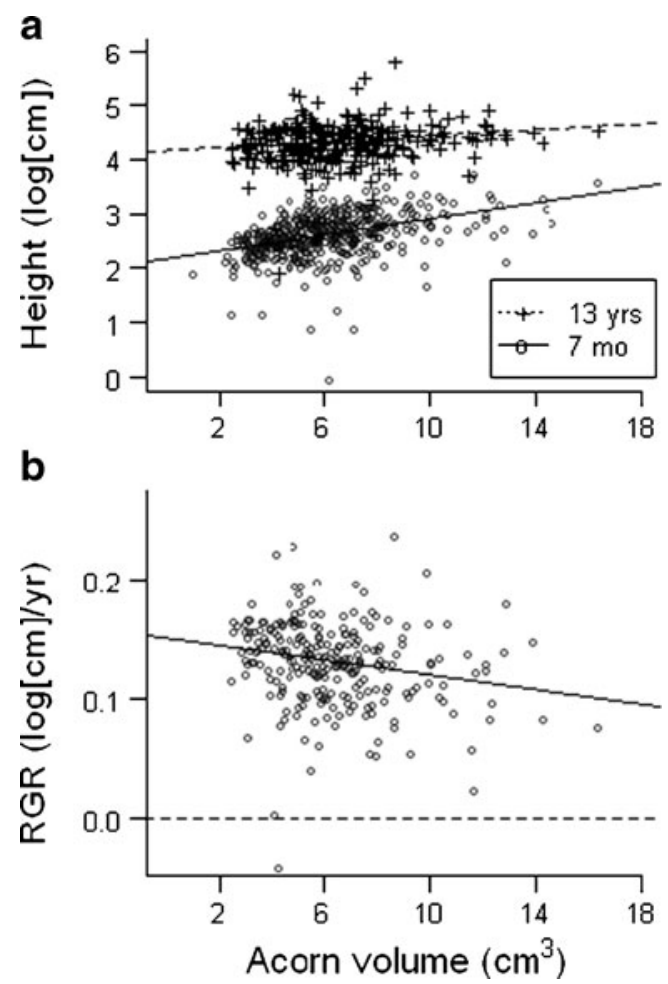

Fig. 3 a Relationship between acorn volume and maximum stem height at the first survey when seedlings were 7 months old (equivalent to RGR during this period) and at the last survey when seedlings were 13 years old. b Relationship between acorn volume and RGR measured from 7 months to when the trees were 13 years old; dashed line at $\mathrm{RGR}=0$. Statistics are summarized in Table 2 

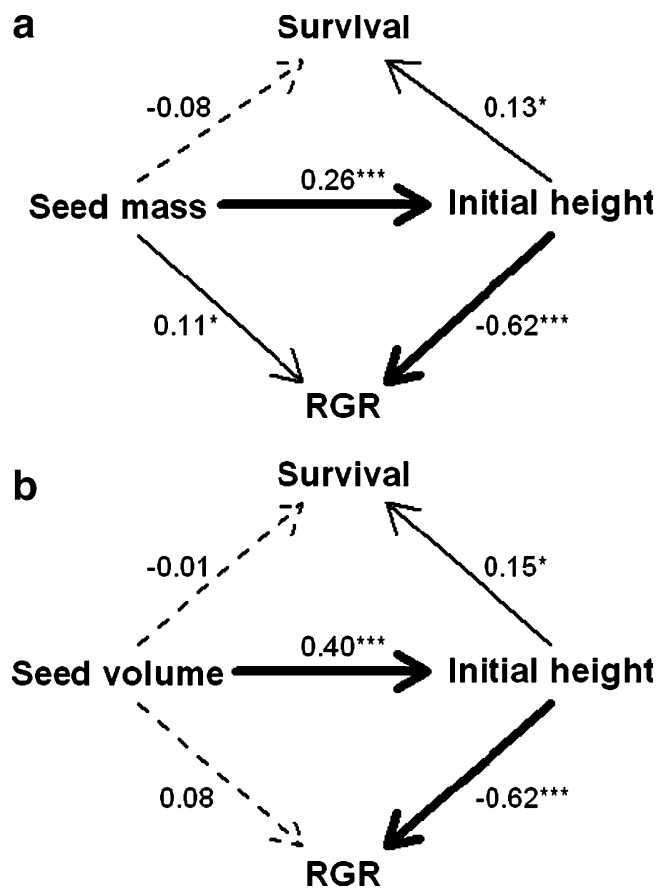

Fig. 4 Path analyses illustrating the direct and indirect effects of initial seedling size along with seed mass (a) and seed volume (b) on long-term seedling performance as measured from the first survey ( 7 months) to the final survey when trees were 13 years old. The strength of the paths is depicted by the type and width of the arrows and by the standardized partial regression coefficients, which are multiplicative. Thin solid line, $* P<0.05$; medium solid line, $\quad * * P<$ 0.01 ; thick solid line, ${ }^{*} * * P<0.001$; dashed line, $P>0.05$

germinating potentially conferring short-term survival benefits), the metabolic effect (seedlings from larger seeds exhibit slower growth rates conferring greater survival over the long run), and the seedling size effect (larger seeds produce larger seedlings that exhibit superior competitive abilities). In contrast to most prior studies (Quero et al. (2007) being an exception), we quantified the fitness effects of varying seed size within a single species measured over both the short and longer term.

Our results confirm some of the complexities of the relationship between seed size and seedling performance that have been found in prior studies. Consistent with all three hypotheses, seed size correlated with larger initial seedling size at 7 months of age, a result matching numerous prior studies, including several with oaks (Dunlop and Barnett 1983; Tripathi and Khan 1990; Tecklin and McCreary 1991; Westoby et al. 1996; Ke and Werger 1999; Gómez 2004; Navarro et al. 2006). More useful for discriminating among the hypotheses was the negative relationship between seed size and initial seedling survival, predicted only by the seedling size effect. The causes of early mortality are unknown; although given that seedlings were protected from most grazing pressure, it is likely that fungal (Christ and Friese 1993) or other pathogens may be playing a role.
Over the longer term, we found evidence for a positive relationship between seed size and seedling survivorship, due primarily to indirect effects mediated though initial seedling height. This relationship was only predicted by the metabolic and seedling size effects. In terms of longer-term relative growth rate, the mixed-effects models revealed a significant inverse relationship with acorn volume (Table 2). However, this relationship was also primarily indirect through the strong effect of initial seedling height on RGR. Controlling for the effect of initial seedling height in the path analyses, we found a weakly significant positive effect of seed mass on RGR (Fig. 4a), a correlation again only predicted by the seedling size effect.

In summary, we found that larger acorns resulted in not only larger seedlings but larger saplings that were taller, greater in basal diameter, and to some extent exhibited greater relative growth rates 13 years after planting than smaller acorns. However, although larger acorns also enhanced long-term survivorship, they suffered greater initial mortality. These relationships support the seedling size effect as being the most important mechanism enhancing the fitness of larger seeds in this species.

It is possible, however, that other effects are sometimes important. The metabolic effect, for example, is most likely to be expressed under particularly unfavorable conditions (Westoby et al. 1996), which may not have characterized conditions during this study due to unusually wet conditions early in the study, the selection of acorns without insect damage, weeding to remove competition, and reduction of herbivory by use of the cages protecting the young sprouts. The influence of the reserve effect is potentially even more complex. Most prior studies of oaks have found that excision of the cotyledon has little or no effect on seedling growth (Jarvis 1963; Sonesson 1994; Andersson and Frost 1996). An exception is the study by Bonfil (1998), who excised cotyledons 1 month after germination and found significant impacts on seedling growth and survival in two species of oaks persisting through the first growing season. More recently, GarcíaCebrián et al. (2003) found that excising the cotyledon from young Quercus robur shoots just after they emerged had no significant effect on early seedling growth once shoots were more than 2 weeks old, while Kennedy et al. (2004) documented several effects of seed reserves on physiology and early growth in $N$. densiflorus but found no effect on seedling biomass of seed removal 64 days after shoot emergence. Although possible effects beyond one or two seasons were not measured in any of these studies, they generally indicate that any reserve effect in oaks declines rapidly during seedling development and is usually complete within 1 to 2 months following germination.

Nonetheless, it is possible that at least some of the reserves found in the large acorns of $Q$. lobata are transferred early on 
to other storage sites in young seedlings where they play an important role in growth or survival at a much later time. García-Cebrián et al. (2003), for example, found that $80 \%$ of the biomass and $73 \%$ of the nitrogen content of seeds had been transferred to $Q$. robur seedlings within 14 days of shoot emergence, but whether such reserves continue to play an important role long after these transfers is unknown. A complete understanding of the role these reserves play in the subsequent life-history of seedlings in this species would clearly require analyses beyond the scope of this study.

We conclude that the seedling size effect plays the most important role in producing the observed relationship in $Q$. lobata between seed size and seedling performance. Although larger seeds tend to produce larger seedlings, this effect appears to come at a cost of higher initial mortality, a tradeoff found in several (Kitajima 1994; Myers and Kitajima 2007) but by no means all (Tripathi and Khan 1990; Baraloto et al. 2005) prior studies. Such trade-offs render the fitness benefits of choosing larger acorns for management and regeneration projects uncertain, especially given the potential importance of other selective factors. For example, within a population, seed predators may prefer larger seeds, leading to selection further countering the growth advantages of larger seeds (Gómez 2004). Equally relevant is the fact that small oak saplings in this habitat may persist for decades despite intense grazing pressure (Koenig and Knops 2007), suggesting that the longer-term benefits of larger seed size expressed after sprouting takes place may be particularly important. These and other factors suggest that different-sized seeds are likely to achieve fitness advantages under differing ecological conditions, thus simultaneously helping to explain the variability in acorn size found within and among species of oaks (Aizen and Patterson 1990; Aizen and Woodcock 1992) and the difficulty of unambiguously determining either optimum acorn size or the factors influencing seed performance. However, when restoration practitioners are able to minimize environmental stressors through irrigation and herbivore exclosures, large seeds do appear to confer longterm benefits to seedling and sapling performance and are thus good candidates for planting stock.

Acknowledgments The authors thank C. Beckmann and the reviewers for comments and the staff of Sedgwick Reserve, particularly Shorty Bucher and Rick Skillin, for assistance during the establishment and maintenance of the plot. Support came from the National Science Foundation (grant DEB-0816691 to WDK) and the Integrated Hardwoods Range Management Program of the University of California.

\section{References}

Aizen MA, Patterson WA (1990) Acorn size and geographical range in the North American oaks. J Biogeogr 17:327-332
Aizen MA, Woodcock H (1992) Latitudinal trends in acorn size in eastern North American species of Quercus. Can J Bot $70: 1218-1222$

Andersson C, Frost I (1996) Growth of Quercus robur seedlings after experimental grazing and cotyledon removal. Acta Bot Neerl 45:85-94

Baraloto C, Forget P-M, Goldberg DE (2005) Seed mass, seedling size and neotropical tree seedling establishment. J Ecol 93:1156-1166

Bonfil C (1998) The effects of seed size, cotyledon reserves, and herbivory on seedling survival and growth in Quercus rugosa and Q. laurina (Fagaceae). Am J Bot 85:79-87

Christ TO, Friese CF (1993) The impact of fungi on soil seeds: implications for plants and granivores in a semiarid shrub-steppe. Ecology 74:2231-2239

Dunlop JR, Barnett JP (1983) Influence of seed size on germination and early development of loblolly pine (Pinus taeda L.) germinants. Can J For Res 13:40-44

Foster SA (1986) On the adaptive value of large seeds for tropical moist forest trees - a review and synthesis. Bot Rev 52:260-299

García-Cebrián F, Esteso-Martínez J, Gil-Pelegrín E (2003) Influence of cotyledon removal on early seedling growth in Quercus robur L. Ann For Sci 60:69-73

Gómez JM (2004) Bigger is not always better: conflicting selective pressures on seed size in Quercus ilex. Evolution 58:71-80

Green PT, Juniper PA (2004a) Seed mass, seedling herbivory and the reserve effect in tropical rainforest seedlings. Funct Ecol 18:539-547

Green PT, Juniper PA (2004b) Seed-seedling allometry in tropical rain forest trees: seed mass-related patterns of resource allocation and the 'reserve effect'. J Ecol 92:397-408

Jarvis PG (1963) The effects of acorn size and provenance on the growth of seedlings of sessile oak. Q J For 57:11-19

Ke G, Werger MJA (1999) Different responses to shade of evergreen and deciduous oak seedlings and the effect of acorn size. Acta Oecol 20:579-586

Kennedy PG, Hausmann NJ, Wenk EH, Dawson TE (2004) The importance of seed reserves for seedling performance: an integrated approach using morphological, physiological, and stable isotope techniques. Oecologia 141:547-554

Kitajima K (1994) Relative importance of photosynthetic traits and allocation patterns as correlates of seedling shade tolerance of 13 tropical trees. Oecologia 98:419-428

Kitajima K (2002) Do shade-tolerant tropical tree seedlings depend longer on seed reserves? Functional growth analysis of three Bignoniaceae species. Funct Ecol 16:433-444

Koenig WD, Knops JMH (2007) Long-term growth and persistence of blue oak (Quercus douglasii) seedlings in a California oak savanna. Madrono 54:269-274

Koenig WD, Knops JMH, Carmen WJ, Sage RD (2009a) No trade-off between seed size and number in the valley oak Quercus lobata. Am Nat 173:682-688

Koenig WD, Knops JMH, Dickinson JL, Zuckerberg B (2009b) Latitudinal decrease in acorn size in bur oak (Quercus macrocarpa) is due to environmental constraints, not avian dispersal. Botany 87:349-356

Kueppers LM, Snyder MA, Sloan LC, Zavaleta ES, Fulfrost B (2005) Modeled regional climate change and California endemic oak ranges. Proc Natl Acad Sci USA 102:16281-16286

Lloret F, Casanovas C, Peñuelas J (1999) Seedling survival of Mediterranean shrubland species in relation to root:shoot ratio, seed size and water and nitrogen use. Funct Ecol 13:210-216

Metcalfe DJ, Grubb PJ (1997) The response to shade of seedling of very small-seeded tree and shrub species from tropical rain forest in Singapore. Funct Ecol 11:215-221

Myers J, Kitajima K (2007) Carbohydrate storage enhances seedling shade and stress tolerance in a neotropical forest. J Ecol 95:383-395 
Navarro FB, Jiménez MN, Ripoll MÁ, Fernández-Ondoño E, Gallego E, De Simón E (2006) Direct sowing of holm oak acorns: effects of acorn size and soil treatment. Ann For Sci 63:961-967

Pavlik BM, Muick PC, Johnson S, Popper M (1991) Oaks of California. Cachuma Press, Los Olivos

Quero JL, Villar R, Marañón T, Zamora R, Poorter L (2007) Seed-mass effects in four Mediterranean Quercus species (Fagaceae) growing in contrasting light environments. Am J Bot 94:1795-1803

R Development Core Team (2009). R: a language and environment for statistical computing. R Foundation for Statistical Computing, Vienna. ISBN3-900051-07-0. http://www.R-project.org

Saverimuttu T, Westoby M (1996) Seedling longevity under deep shade in relation to seed size. J Ecol 84:681-689

Sonesson LK (1994) Growth and survival after cotyledon removal in Quercus robur seedlings, grown in different natural soil types. Oikos 69:65-70

Stanton ML (1984) Seed variation in wild radish: effect of seed size on components of seedling and adult fitness. Ecology 65:1105-1112

Stearns SC (1989) Trade-offs in life-history evolution. Funct Ecol $3: 259-268$
Tecklin J, McCreary DD (1991). Acorn size as a factor in early seedling growth of blue oaks. In: Standiford R B [tech. coord.] Proceedings of the symposium on oak woodlands and hardwood rangeland management, USDA Forest Service General Technical Report PSW-126, Pacific Southwest Forest and Range Experiment Station, Berkeley, California, USA, pp 48-53

Tripathi RS, Khan ML (1990) Effects of seed weight and microsite characteristics on germination and seedling fitness in two species of Quercus in a subtropical wet hill forest. Oikos 57:289-296

Tyler CM, Kuhn B, Davis FW (2006) Demography and recruitment limitations of three oak species in California. Q Rev Biol 81:127-152

Westoby M, Leishman M, Lord J (1996) Comparative ecology of seed size and dispersal. Phil Trans Roy Soc London B 351:1309-1318

Wright IJ, Westoby M (1999) Differences in seedling growth behaviour among species: trait correlations across species, and trait shifts along nutrient compared with rainfall gradients. J Ecol 87:85-97

Zavaleta ES, Hulvey KB, Fulfrost B (2007) Regional patterns of recruitment success and failure in two endemic California oaks. Divers Distrib 13:735-745 